\title{
DESIGNING READING MATERIALS FOR THE FACULTY OF SOCIAL AND POLITICAL SCIENCES AT UIN SYARIF HIDAYATULLAH JAKARTA
}

\author{
Devi Yusnita \\ Syarif Hidayatullah State Islamic University of Jakarta \\ (devippb@uinjkt.ac.id)
}

Received: $23^{\text {th }}$ March 2015; Revised: $25^{\text {th }}$ April 2015; Accepted: $25^{\text {th }}$ May 2015

\begin{abstract}
This research is aimed to design reading materials for the Faculty of Social and Political Sciences, UIN Syarif HIdayatullah Jakarta, due to the absence of such specific materials in the market. To produce satisfactory teaching materials, the researcher did some steps i.e. doing needs analysis, reviewing the principles of materials design and reading strategies, designing course framework, designing syllabus, designing the reading materials, and implementing the sample lessons. The needs analysis was intended to find out what the students needed and to find out the subjects the students learned from the institution in order to produce adequate reading materials. Based on the needs analysis, the researcher then identified the global aims of the course, thereby, the writer designed course framework. This course framework contained general points of reading themes and topics, information of classroom activities that followed up reading, the length of study session, the number of the course meetings, and the number of participants. The course framework became the basis to write the syllabus. Finally the syllabus became the basis for designing reading materials.
\end{abstract}

Key words: social and political sciences; material design; syllabus; textbook

\section{ABSTRAK}

Penelitian ini bertujuan menyusun materi membaca (reading) pada matakuliah Bahasa Inggris untuk Fakultas Ilmu Sosial dan Politik (FISIP), UIN Syarif Hidayatullah Jakarta dikarenakan sulitnya mencari materi sejenis bagi mahasiswa FISIP. Untuk menghasilkan materi pengajaran yang baik, peneliti melakukan beberapa langkah, yaitu melakukan analisa kebutuhan, mempelajari prinsip-prinsip penyusunan materi dan strategi reading, menyusun kerangka matakuliah, menyusun silabus, menyusun materi reading, dan mengimplementasikan contoh materi di kelas. Analisa kebutuhan bertujuan untuk mengetahui kebutuhan mahasiswa dan matakuliah yang dipelajari dari fakultas terkait agar materi reading yang disusun sesuai dengan kebutuhan mahasiswa. Berdasarkan hasil analisa kebutuhan, peneliti mengidentifikasi tujuan utama perkuliahan bahasa Inggris di FISIP yang kemudian digunakan untuk menyusun kerangka matakuliah. Kerangka matakuliah ini berisi poin-poin umum seperti tema dan topic reading, informasi tentang aktifitas lanjutan setelah kegiatan membaca, waktu pembelajaran, dan jumlah mahasiswa. Kerangka matakuliah ini menjadi dasar untuk penyusunan silabus yang akan digunakan untuk menyusun materi reading.

Kata kunci: ilmu sosial dan politik; desain material; silabus; buku pelajaran

How to Cite: Yusnita, D. (2015). Designing Reading Materials for the Faculty of Social and Political Sciences at UIN Syarif Hidayatullah Jakarta. IJEE (Indonesian Journal Of English Education), 2(1), 27-44. doi:10.15408/ijee.v2i1.2002

Permalink/DOI: http:/ /dx.doi.org/10.15408/ijee.v2i1.2002 


\section{INTRODUCTION}

To master English, one needs to be good at the four language skills i.e. reading, writing, listening, and speaking. Reading, for example, is one of the crucial language skills since there are a lot of advantages students can obtain from this skill. They can improve their vocabularies and expand their knowledge. Komiyama (2009, p. 32) says that "reading is an important skill for English language learners in today's world; it supports the development of overall proficiency and provides access to crucial information at work and in school".

At the university level, reading in English as a foreign language is taught mostly for the purpose of making students able to read textbooks written in English. This happens to the institutions where the researcher teaches. To be able to support their research when writing a thesis or doing a final project as one of the requirements to finish their education, they need to read more books or scientific journals to find the underlying theory. In this step they usually start to realize that English is actually very important.

A number of ready-made English textbooks that focus on reading are a lot. Some big publishers such as Longman, Cambridge, and Pearson have published English books for most fields of study, ranging from economics to engineering. English lecturers do not have to worry about framework since most English textbooks are written by the experts, and ready-made textbooks usually provide very clear framework. One of the advantages of using readymade material is practicality. Crawford (in Jack C. Richards and Willy A. Renandya, 2002) mentions that "readymade textbooks save teachers' time, enabling teachers to devote time to teaching rather than materials production (p.66)".

Apart from their advantages, ready-made materials also have drawbacks. One of the drawbacks of rigidly using commercial materials is they do not always fulfill English learners need. As we know, the English proficiency of learners is diverse. Mostly ready-made or commercial materials are not capable of catering this diversity. This is similar to what Nunan (1995) says that "one of the major concerns is that any given course book will be incapable of catering for the diversity of needs which exists in most language classrooms (p. 206)".

In the field of English for Specific Purposes (ESP), the problems are similar. Commercial textbooks are mostly incapable of catering the learners' need. Very often the content of 
commercial ESP textbooks does not match certain conditions such as the needs of students and the level of difficulty. Bouzidi (2009) states that "an important component of an effective ESP course is a textbook that contains job-related English lessons. However, there is often a mismatch between the content of ESP textbooks and actual workplace language demands (p.10)".

Teaching reading to students majoring in social and political sciences needs the materials. Ideally, the materials can equip the students to make them able to read the textbooks for the sake of their study and professional development. Unfortunately, such materials are scant in the market. Using commercial materials for teaching-learning process that are not really related to the field of study seems to be ineffective. This is actually what Ur (2000) says concerning commercial materials that, "the topics dealt in the course book may not necessarily be relevant or interesting for your class. Every class, in fact, every learner has their own learning needs: no one course book can possibly supply these satisfactorily (p. 185)". Therefore, the researcher feels challenged to design reading materials that fulfill the needs of the students majoring in social and political sciences. The reading materials are expected to be able to provide the students studying social and political sciences with sufficient vocabularies and skills in reading English textbooks.

Tomlinson (2008) states that "materials could obviously be cassettes, videos, CD-Roms, dictionaries, grammar books, readers, workbooks or photocopied exercises. They could also be newspapers, food packages, photographs, live talks by invited native speakers, instructions given by a teacher, tasks written on cards or discussions between learners. In other words, they can be anything which is deliberately used to increase the learners' knowledge and/or experience of the language (p. 2)".

In designing the course material, it is of course necessary to look at curriculum as one of the main references in the material development. Curriculum is a broader concept that includes not only what pupils learn, but how they learn it, and how teachers help them learn, using what supporting materials, styles and methods of assessment, and in what kind of facilities (Rodgers, 1994). The development of materials must be preceded by program framework (program blueprint) and course syllabus, which should refer to the curriculum. 
There are some assumptions underlying early approaches to syllabus design, which serve as the guideline for materials design and development. The first assumption is that the basic units of language are vocabulary and grammar. This traditional approach to English language teaching prioritizes vocabulary and grammar as the main building blocks of language development (Richards, 2007). The second underlying assumption sees that learners everywhere have the same needs. It was believed that the core vocabulary of English, combined with grammatical syllabus, would serve as the basis for almost all language courses. The third assumption is that learners' needs are identified exclusively in terms of language needs. Syllabus design is solely based on language needs of learners. The fourth assumption is that the process of learning a language is largely determined by textbook. As the primary input for learners to get from the language learning process, the selection and gradation as the ways of controlling the textbooks' context and facilitating the language learners are deemed important. The fifth assumption is regarding to the context of teaching English as a foreign language. This underlying assumption of syllabus design is similar to the condition in Indonesia. As a foreign language, English is rarely spoken among Indonesians. Therefore, this factor should be taken into account in designing the syllabus.

Compared to curriculum, syllabus nowadays becomes the central point of teaching-learning activities. Rodger (1994, p.25) states that "at the heart of the educational enterprise is the educational program offered. Until fairly recently most educational authorities have considered the syllabus to be the educational program. It has been the syllabus, which has received the most attention in educational design and implementation. It has been syllabus reform, which has been seen as central to educational reform. When new educational goals are sought or old goals are felt to have been inadequately realized, specification of a new syllabus has been the typically favored solution." To sum up, syllabus is part of curriculum. In designing a syllabus in the field of ESP, there must be needs analysis. Because the researcher designs reading materials for social and political sciences that is categorized as English for Specific Purpose (ESP), then it is necessary to also discuss about ESP and course material design.

Syllabus in ESP is developed from the needs analysis of the target learners. ESP, according to Dudley-Evan and St John (2002), has two distinctive 
characteristics, i.e. absolute and variable characteristics. The absolute characteristics of ESP are that ESP is designed to meet specific needs of the learner, makes use of the underlying methodology and activities of the disciplines it serves, and is centered on the language (grammar, lexis, register), skills, discourse and genres appropriate to these activities. On the other hand, the variable characteristics of ESP are that ESP may be related to or designed for a specific discipline, may use, in specific teaching situation, a different methodology from that of general English, is likely to be designed for adult learners, either at a tertiary level institution or in a professional work situation, and is generally designed for intermediate or advanced students.

In ESP, needs analysis is the key in the course design. Today's concept of needs analysis, according to DudleyEvans and St. John (2002), includes some aspects. The first aspect is professional information about the learners. This is to find out the task and activities learners are/will be using English for. The second aspect is personal information about the learners. This is to see factors, which may affect the way learners learn. Those factors encompass previous learning experiences, cultural information reasons for attending the course and expectation of it, and attitude to English. The third aspect is English language information about the learners. This is important to find out what learners' current skills and language use are. The fourth aspect is language learning information. This is done to find out the effective ways of learning the skills and language. The fifth aspect is professional communication information about knowledge of how language and skills are used in the target situation. The sixth aspect is to find out what is wanted from the course, and the final aspect is information about the environment in which the course will be run.

Graves (2000, p. 100) proposes the process of needs assessment. She states that "the process of needs assessment involves a set of decisions, actions, and reflections that are cyclical in nature. The cyclical process starts from deciding what information to gather and why, deciding the best way to gather it: when, how and from whom, gathering the information, acting on information, evaluating the effect and effectiveness of the action, and formally back to number one to decide on further or new information to gather."

The questions appearing now is who provides the data and how? Dudley Evans and St John (2002) 
suggest that for needs analysis the main sources to collect are the learners, people working or studying in the field, ex-students, documents relevant to the field, clients, employers, colleagues, and ESP research in the field. To collect the data, the methods may include questionnaires, analysis of authentic spoken and written texts, discussions, structured interviews, observations, and assessments.

Due to the characteristics of ESP which is focusing on specialist subjects, and due to unavailable commercial materials, very often ESP teachers need to design or develop the materials themselves. In fact, there are some advantages of creating our own teaching materials. Richard (2007) mentioned that teacher-made materials are: 1) directly relevant to students' and institutional needs; 2) help develop expertise among staff; 3) enhance the reputation of the institution; 4) offer greater flexibility than a commercial course book for the institution to revise and adapt.

Almost similar to what Richards says, Howard and Major also (2010) state the advantages of why English language teachers may choose to design their own materials. The first advantage, according to Howard and Major, is contextualization. For many teachers, designing their own teaching materials enables them to take into account their particular learning environment and to overcome the lack of 'fit' of the commercial course book. The second advantage concerns individual needs. Howard and Major (ibid) assert that identifying individual needs of students are increasingly promoted in the teaching and learning process so that teachers are responsive to the heterogeneity inherent in the classroom. It can be concluded that by designing our own materials, we can cater more students, especially in the class having students with various background. The third advantage is personalization. According to Block (in Howard and Major, 2010), 'home-made' materials add personal touch to teaching that students appreciate. The last advantage why English language teachers may choose to design their own materials, according to Howard and Major, is timeless. It means that teachers designing their own materials can respond to local and international events with up to date and relevant topics.

Howard and Major (2010) also suggest some guidelines for designing effective English teaching materials. The first is that English language teaching materials should be contextualized. Materials should link explicitly to what the learners already 
know, to their first language and cultures, and very importantly, should alert learners to any areas of significant cultural difference. In addition, materials should be contextualized to topics and themes that provide meaningful as well as purposeful uses for target language. The second is that materials should stimulate interaction and be generative in terms of language. The third is that English language teaching materials should encourage learners to develop learning skills and strategies. It is impossible for a teacher to teach his students all the languages they need to know in the short time. It is essential that language teaching materials also teach their target learners how to learn and help them to take advantage of language learning opportunities outside the classroom. Finally, English language teaching materials should be flexible and authentic. It is imperative for second language learners to be regularly exposed in the classroom to real, unscripted language-to passages that have not been produced specifically for language learning purposes.

In terms of authentic materials, Fathi (2010) states that authenticity is a very important concept that should be considered as part of teaching/learning process. Similarly, Richard (2007) argues that authentic materials are preferred over created materials, because they contain authentic language and reflect real-world uses of language compared with the contrived content of much created material.

Several authors such as Phillips and Shettlesworth (1978), Clarke (1989), and Peacock (1997) in Richards (2007) have identified some advantages of using authentic material in materials design.. According to them, authentic materials have a positive effect on learner motivation, provide authentic cultural information about the target culture, provide exposure to real language, relate more closely to learners' needs, and support a more creative approach to teaching.

To sum up, in designing teaching materials, there are some points as previously mentioned that should be taken into account. One important aspect is using authentic materials. Since the researcher would like to design reading materials for social and political sciences, and the information of this subject is mostly written in English, using authentic materials taken from real sources such as textbooks, internet articles, journals, and newspaper articles are worth trying.

Furthermore, considering students especially university students must have sufficient level of reading skills, it is necessary to facilitate them 
with reading skills. Therefore, it is essential to look into some principles of reading in a foreign language in order that the materials the researcher design have the underlying theories and be useful for the learners. There are some approaches regarding teaching reading in a foreign language. They are bottomup approach, top-down approach, and interactive approach. Bottom-up approach in reading can be illustrated as a person who tries to understand an area by discovering every part and checking what is inside. After roaming the whole area, he/she will understand what it looks like. Top-down approach is the contrary of bottom-up approach. Top-down approach can be illustrated as a person who tries to understand an area from the air. He or she could be described as a person getting on balloon flying around in the sky. He or she will understand the nature of the area by getting a picture of it. Interactive approach is the combination of those two approaches.

Nuttal (2000, p. 18) states that "in practice a reader continually shifts from one focus to another, now adopting a top-down approach to predict the probable meaning, then moving to the bottom-up approach to check whether that is really what the writer says. This has become known as interactive reading." It is clear that the combination of bottom-up and top-down approach will give more benefit to the students. Therefore, the reading materials the researcher designs adopt the interactive approach.

Considering interactive approach, Axbey (cited in McGrath, (2006, p. 146) proposes standard reading exercises. Axbey's framework is divided into three stages i.e. pre-reading, while reading, and post reading. Pre-reading activities include drawing upon existing knowledge, exploiting areas of interest, and encouraging prediction of content, language and function. Whilereading activities can consist of two stages: 1) confirming and checking, and understanding global meaning and shape, and 2) understanding main points, dealing with vocabulary, and being aware of writer's purpose. In post reading activities, the students can be asked to give a personal response and encourage self-awareness of difficulties.

Similar to Axbey, Grabe (1986) and Seright and Thomson (2010) also suggest some activities pertaining to reading skills and strategies to enable students to develop skills or strategies which facilitate reading comprehension. The strategies are guessing the meaning of unfamiliar words through the use of context clues and analysis of component parts (stems and affixes), locating core elements in long, complex 
sentences, understanding cohesive devices such as pronoun reference and logical connectors, identifying the main idea and supporting details, determining the sequence of steps or events, predicting text content, skimming, scanning for specific facts, making inferences, and distinguishing between fact and opinion or supposition. To summarize, there are some strategies and techniques in order to facilitate reading in a foreign language. The concepts of the strategies and approaches above will be the researcher's consideration in designing the reading materials. So, the finished product that is in the form of course book will be more beneficial for the learners.

Considering the absence of learning materials and the principles of developing learning materials as presented in this section, the researcher therefore proposes a study intended to answer the following research questions:

1. What are the students' needs according to the stakeholders (students, alumni, and institution)?;

2. What are the principles of materials design in language teaching?;

3. What are the processes of designing reading materials?
There are three points of significance by doing this study. First, this research is expected to be beneficial for English lecturers teaching reading to students majoring in social and political sciences. Second, the materials can equip the students to be able to read and understand the textbooks of their field of study. By having sufficient reading skills, together with linguistic concepts, the students can develop their knowledge to grasp the development of social and political sciences. Third, the study is expected to give valuable contribution for those who are interested in designing teaching materials of English for Specific Purposes. Since job specialization keeps increasing, people need to equip them with English needed in their field of job. In the future, English materials specializing in certain profession are very much needed.

\section{METHOD}

The goal of this research was designing reading materials for social and political sciences that would be used at the faculty of social and political sciences (FISIP) of UIN Syarif Hidayatullah Jakarta. The final product of the research was reading materials in the form of a conventional material or course book. The research applied qualitative inquiry. Referring to the 
conceptual theory of a case study, the researcher conducted four steps in order to produce reading materials. The steps were doing needs analysis, designing course framework, designing syllabus, designing reading materials, and implementing (piloting) the sample lessons.

In the needs analysis, a questionnaire was distributed to the students of FISIP (30 students, randomly selected from three majors of the faculty), the alumni of the institution (5 persons, who happened to come to the meeting organized by the researcher), and the institution itself (represented by the head of the three departments of the faculty). The main purpose was to find out what they really needed with respect to reading materials design and English lesson. The research activities stemmed from administering questionnaires for students, alumni, stakeholders, analyzing the data from those questionnaires, designing course framework, designing syllabus, designing reading materials, and implementing sample lessons.

Concerning the course framework, referring to the results of the need analysis, the researcher then identified the global aims of the course, namely enhancing reading skills and introducing the elements of linguistic input and subject input. This course framework contained general points of reading themes and topics, information of classroom activities that followed up reading, the length of study session, the number of the course meetings, and the number of participants. The course framework became the basis to write the syllabus, which outlined course book in detail concerning reading texts and classroom activities and strategies. The syllabus also acted as guidance for producing reading materials. In developing materials, the researcher put texts taken from internet, newspaper, and textbook by adapting and adopting. The researcher preferred adopting to adapting the texts since the researcher wanted to keep the authenticity of the texts. The researcher only adapted the texts when they were suited to the reading activities.

In the implementation stage, the researcher piloted the sample unit, which was intended to find out the responses of the students toward the materials designed. The researcher distributed the questionnaires after implementing certain lesson. The points of questionnaires were whether the material was suitable to the students' field of study or not, whether the material was understandable or not, whether the material was interesting for the students or not, whether, in general, 
the material was satisfactory or not, and comments for material improvement (if there is any).

\section{FINDINGS AND DISCUSSION}

This section discusses the important findings of the research, which will be divided according the three research questions.

What are the students' needs?

The research shows that the students need firstly to learn English since they still find difficulty in using the language. Secondly, they need to learn the four skills with the emphasis on reading and speaking. Nevertheless, the students think that the four language skills are important for their success in study and career. That indirectly concludes that the students are aware of the importance of English for both their education and their future career. Thirdly, they need reading texts taken from textbooks, newspaper, and internet to broaden their knowledge. Finally, they need to know and understand reading strategies such as skimming, scanning, guessing word meaning from context, finding word referent, and making inferences. The strategies are important to help them read English texts.

The difficulty faced by the students becomes the focus of attention by the researcher. In designing the teaching materials, even though the focus is on reading the researcher also put speaking and writing activities. In the reading materials, by the end of each lesson, the researcher put 'expansion'. The expansion consists of speaking and writing activities. For speaking, the activities are mostly discussion and presentation while the writing activities are mostly report and essay writing.

Concerning the reading texts, the students want to read journal articles, internet articles, newspaper articles, and textbooks although they recognize the difficulty of reading such texts. This provides important information on the types of reading texts that should be included in the design. Besides, all the passages are related to the subject the students are learning. This is done to expose the students with various kinds of text, and make them accustomed to the text genre.

Another point that should be considered is the fact that the students are not quite accustomed to the reading strategies or skills in understanding reading texts. This could be one of the reasons why they think texts are difficult. They do not know the strategies to attack reading texts to get the information needed. In fact, the institution also complains that the 
students do not have adequate underlying theories when writing their final project.

Knowing this, the researcher includes some reading strategies that are mostly used by experience readers. Those strategies are skimming, scanning, guessing meaning from context, pronoun referent, and making inferences. These strategies are worth including in all reading activities, and that is what the researcher applies in the reading materials. With respect to vocabulary, the researcher put the exercise for developing vocabulary in each lesson. The exercises are not only words in general but also specific words related to the terms found in the field of social and political sciences. In short, what the students need from reading materials designs has been fulfilled. The course book caters what the students expect to learn, and it also pays attention to the reading strategies proposed by experts in understanding passages.

This research also reveals that the alumni need English in their job. They need to understand the four skills well because all four skills in English are important for their success in their job. Yet, they emphasize the importance of especially speaking. That is why in designing reading materials, the researcher includes speaking and writing activities. Furthermore, the institution needs its students have a good ability in reading English texts since most books in social and political sciences are written in English.

In terms of difficulties, most alumni find are they are not sure how to pronounce words correctly, have difficulty in starting and expressing ideas, feel nervous to start conversation, and think that they lack vocabularies to express their opinion. To overcome this problem, the researcher spares vocabulary exercises in the reading materials. In writing, the difficulties include not knowing how to use words concisely and grammar correctly. As a result, they often use and follow Indonesian patterns in writing because they do not know how to arrange words for sentences, they do not know the spelling, and finally they lack English vocabulary. Therefore, the reading materials the researcher designs include writing activities, which focus on essay writing and report writing.

In terms of reading, half of the alumni inform that they have difficulties to understand texts because accordidng to them they lack vocabularies. Those two problems are the reasons why they think reading is difficult. This gives the researcher an idea of incorporating reading strategies 
-as previously written -to equip the students to have sufficient skills in reading in a foreign language.

Furthermore, from the questionnaire for the institution, the research finds some purposes of giving English lesson focusing on reading. Firstly, it is to make students have the ability to read and comprehend textbooks especially those that related to the theory of social and issues of social and political sciences. Secondly, it is to encourage students to read English textbook a lot and pleased to read English resources. Thirdly, it is as a trade mark of English teaching-learning process in FISIP.

Clearly, this gives information to the researcher that the institution expects the students to be able to read English textbooks and passages related to the subject of social and political sciences. The skill is very important for the students to expand their knowledge and to base their theory when reading English textbooks. It is also hoped that by exposing students to reading texts, they can improve their speaking and writing skills. Regarding the reading texts to be taught in the classroom, the institution expected that the students be taught English texts taken from journals, newspaper articles, internet articles, and textbooks. That is why the researcher includes such texts in the reading materials.

To conclude, both the alumni and institution put forward ideas that English is important. Three skills that are emphasized include reading, writing, and speaking. However, it is also clear that reading becomes the most emphasized skill of the the institution. Therefore, the researcher focuses on designing reading materials by supplementing the materials with speaking and writing activities.

What are the principles of materials design in language teaching?

Brown (1995, p. 138) states that everything contributing to classroom teaching can be categorized as materials, therefore it is not restricted to course book. As a matter of fact, the researcher limits the materials design in this research only to a paper-based concept. The researcher designs reading materials to be used in the classroom by the students majoring in social and political sciences.

Why are materials important in teaching-learning context? As previously mentioned, there are four reasons. First, they function as a source of language. Second, they function as a learning support. Third, they function as motivation and stimulation. Fourth, they function as a reference. 
The research finds out that there are also five advantages of creating our own teaching materials. Among advantage are materials can be produced thatare directly relevant to students' and institutional needs, materials can help develop expertise among staff, materials can enhance the reputation of the institution, and materials produced within the institution can be revised or adapted as needed. Therefore, it is more flexible than commercial course books, and finally for many teachers, designing their own teaching materials enables them to consider their particular learning environment so as to overcomes the lack of commercial course books.

The literature research finds that there are some principles of designing teaching materials. Firstly, English language teaching materials should be contextualized. It means that materials should link explicitly to what the learners/students already know, their first language and cultures. In addition, materialsshould be able to alert the learners to any areas of significant cultural difference by providing contextualized topics and themes that provide meaningful and purposeful uses of the target language.

Secondly, materials should stimulate interaction and be generative in terms of language. It means that materials can be the media for the interaction between students and students, and between students and the teacher. Thirdly, English language teaching materials should encourage learners to develop learning skills and strategies. It is impossible for teachers to teach their learners all the language they need to know in the short time. It is essential that language teaching materials also teach their target learners how to learn and help them to take advantage of language learning opportunities outside the classroom.

Fourthly, English language teaching materials should be authentic. It is beneficial for second language learners to be regularly exposed in the classroom to real and unscripted languages and texts that have not been produced specifically for language learning purposes. Authentic materials have a positive effect on learner motivation, provide authentic cultural information about the target culture, provide exposure to real language, relate more closely to learners' needs, and support a more creative approach to teaching.

From the above-mentioned points, the researcher relates the principles of teaching materials design to reading materials the researcher designs. In designing reading materials, 
the researcher includes authentic texts. All texts are taken from textbook, internet articles, and newspaper articles. In some lessons, the texts are adapted to the questions the researcher makes.

Referring to the second principle that materials should stimulate interaction, the researcher put prereading activities in the form of questions. After that, by the end of the lesson, the researcher put 'expansion' for speaking and writing activities. Speaking activities can be in the form of presentation and debate that surely can stimulate interaction among students.

Reading strategies and skills that exist in the reading materials that the researcher designs prove that the materials fulfill the third principle of designing teaching materials. The principle says that English language teaching materials should encourage learners to develop learning skills and strategies. It is hoped that the students can develop the strategies and skills outside the classroom. To conclude, the reading materials the researcher design have fulfilled the principles of designing teaching material that cover authentic texts, interaction, and strategies. The reading materials have also been implemented with satisfying comments and responses from the students. Therefore, they are ready to use.

What are the processes of designing reading materials?

There are some steps the researcher does in designing reading materials for social and political sciences. Those steps are doing needs analysis, designing course framework, designing a syllabus, designing the materials, and implementing (piloting) sample unit.

Needs analysis is done to three parties i.e. students, alumni, and institution. Needs analysis for students is done to find out what the students need and to find out the subjects the students learn from the institution in order to produce adequate reading materials. Finding out the subject matters is important since the content of reading materials is about social and political sciences, and the researcher needs to know what the students are learning before making the teaching materials.

The needs analysis for alumni and institution is done to find out what alumni and institution want from English lesson. It could benefit in designing the teaching materials. At least the researcher knows the expectation of other parties - apart from the students themselves - and could 
cater that expectation. Some purposes of doing the needs analysis are collecting information about particular information and problem learners are experiencing and identifying a gap between what students are able to do and what they need to be able to do.

In summary, there are some steps to do to design teaching materials. The step starts from finding what the students and institution need, designing course framework, designing the syllabus, designing the material, and implementing the material (sample lessons).

\section{CONCLUSION AND SUGGESTION}

Based on the findings and discussions, the researcher draws some points in conclusions. First of all, the students of FISIP need to learn the four language skills with the emphasis on reading and speaking. Then, they need to read English texts taken from textbooks, internet, and newspaper. Finally, they need reading skills and strategies to understand English texts.

Second, the institution needs its students to be able to read and understand English textbooks, while the alumni consider that the four language skills are important in their job. The alumni also emphasize the importance of speaking compared to the other skills and vocabulary mastery to support the attainment of the skills to cummunicate and read.

Third, concerning the development of materials, there are some principles that should be considered. The first principle is that materials should be contextualized. Then, materials should stimulate interaction. The interaction includes students and students as well as students and the teacher. Next, materials should encourage learners to develop learning skills and strategies. And finally materials should be authentic.

Fourth, in designing framework, there are some points to be taken into account. Those points cover the global aims of the course, general points of reading themes and topics, information of classroom activities, the length of study session, the number of the course meetings, and the number of participants. The information can surely contribute to the making of syllabus.

Fifth, syllabus design is another step that is crucial enough in designing teaching materials. The syllabus outlines teaching materials in detail concerning reading texts, topics, and classroom activities and strategies. In designing the teaching materials, the syllabus must be the reference and guidance. 
Sixth, the last step in designing teaching materials is implementation. Implementation is piloting the sample unit. This is to know whether the materials we have designed successful or not. Besides, this is done to see the comments and responses from the students. After all, they are the ones who will learn from that teaching material.

\section{REFERENCES}

Bouzidi, Hassan. 2009. Between the ESP

Classroom and the Workplace: Bridging the Gap. English Teaching Forum 47.

Brown, J.D. 1995. The Element of Language Curriculum. Boston: Heinle and Heinle Publishers.

Eskey, David E. 1986. Teaching Second Language Reading for Academic Purposes. The USA: AddisonWesley Publishing Company, Inc.

Grabe, William. 1986. The Transition from Theory to Practice in Teaching Reading. In Eskey, David E (ed). Teaching Second Language Readingfor Academic Purpose. The USA: AddisonWesley Publishing Company, inc.

Howard, Jocelyn and Major, Jae.

'Guidelines for Designing Effective English Language Teaching Materials'. http://www. paaljapan.org/resources/ proceeding/PAAL9/pdf. (accessed February 6, 2010) 95.

Hudson, Thorn. 2007. Teaching Second Language Reading. Oxford: Oxford University Press.

Kathleen Graves. 2000. Designing Language Course: A Guide for Teachers. Canada: Heinle \& Heinle Publishers.

Keith Johnson, Robert. 1994. The Second Language Curriculum. Cambridge: Press Syndicate of the University of Cambridge.

Komiyama, Reiko. 2009. "CAR: A Means for Motivating Students to Read": English Teaching Forum. Volume 47 Number 3, 2009.

McGrath, Ian. 2006. Materials Evaluation and Designfor Language Teaching. Edinburgh: Edinburgh University Press Ltd.

Nunan, David. 1995. Language Teaching Methodology: A Textbook/or Teachers. Maryland: Phoenix EL T.

Nuttal, Christine. 2000. Teaching Reading Skills in a Foreign Language. UK: Macmillan Education.

Richards, Jack C and Renandya, Willy A (Eds.). 2002. Methodology in Language Teaching: An Anthology o/Current Practice. United Kingdom: Cambridge. 
Richards, Jack C. 2007. Curriculum Development in Language Teaching. Cambridge: Cambridge University Press.

Seright, Linda and Thompson, Joan. Developing Reading Materials for Advanced ESL Learners. http://www.teslcanadajourna1.c o/index.php/tesllarticle (accessed February 3, 2010).

Theodore S. Rodgers. 1994. Syllabus Design, Curriculum Deveopment and Polity Determination. In Robert Keith Johnson (ed.) The Second Language Curriculum. Cambridge: Press Syndicate of the University of Cambridge.
Tomlinson, Brian. 2008. Materials Development in Language Teaching. United Kingdom: Cambridge University Press.

Tony Dudley-Evans and Maggie Jo St John. 2002. Developments in ESP: A multi-disciplinary approach. Cambridge: The Press Syndicate of the University of Cambridge.

Ur, Penny. 2000. A Course in Language Teaching: Practice and Theory. United Kingdom: Cambridge. 